\title{
After Covid-19: urban design as spatial medicine
}

\author{
Louis Rice $^{1}$
}

Accepted: 1 October 2020

(c) Springer Nature Limited 2020

\begin{abstract}
This article draws out key implications for urban designers from the Covid-19 pandemic, particularly the relation between urban design and health. The entire world is facing the same acute health emergency of Covid-19 which is already impacting half of the global population, and as the majority of the world now inhabits urban settings, urban dwellers are the most affected. Urban Design already plays an important role in determining the health of urban populations but this relationship is often unclear, undervalued or ignored. The field of medicine is expanding to include all professionals who have an impact on the health of others, and this expanded field includes the urban design profession. After Covid-19, urban design ought to become a form of spatial medicine, whereby the design of built environments positively contributes and facilitates human and planetary health and wellbeing.
\end{abstract}

Keywords Covid-19 $\cdot$ Coronavirus $\cdot$ Urban design $\cdot$ Healthy cities $\cdot$ Wellbeing

\section{Context: Covid-19 and urban health}

Within months of its arrival, Covid-19 already affected the lifestyles of billions of people worldwide-as a direct response to a health issue. The Covid-19 event could arguably be described as the biggest medical, social, economic and cultural experiment in human history. Governments worldwide are revising their policies to avert Covid-19; this dramatic foregrounding onto one single issue, i.e. 'health', is rarely enacted outside of wartime. A consequence of Covid19 has been the sudden and significant change in the way we live, with new and unfamiliar modes of behaviour required during the pandemic lockdown. What society might learn from this 'living laboratory' on wellbeing is still unfurling. However, this heterogenous period offers a unique opportunity to understand the pre- and post-Covid-19 implications for urban design. Over half of the global population is now in some form of lockdown condition restricted to their homes and neighbourhoods (deSantis 2020). Whilst this has precipitated untold disruption and many challenges, it has also become a period of reflection. At the heart of the

Louis Rice

Louis.Rice@uwe.ac.uk

1 Department of Architecture and the Built Environment, University of the West of England, Frenchay Campus, Bristol, UK
Covid-19 epidemic is greater focus and public attention on the relationship between contemporary urban lifestyles and health.

\section{Cities under pre- and post-Covid-19 conditions}

During the Covid-19 lockdown, there are changes to the determinants of health, the diverse range of environmental, economic and social factors that impact on human wellbeing, compared to the pre-Covid period. The current focus of Covid-19-related policy is targeted on human health. The initial period is all about reducing deaths and illness from one particular infection (almost regardless of economic or other costs). Aside from the direct impacts of the Covid19 virus on physical health, there are a number of associated and indirect harmful repercussions on health including loneliness, depression, domestic violence and the unintended consequence of people not accessing hospital for e.g. cancer treatments (Dore 2020; Douglas et al. 2020). The social isolation practices currently experienced during Covid-19 lockdown are highlighting the importance of 'social' health. Conversely, there are also some beneficial consequences of lockdown to health, for example, many urban areas have experienced significant reductions to air pollution, noise pollution, traffic congestion, crime, whilst also seeing increases 
in active travel such as walking/cycling (particularly for people who would not normally undertake these activities) and a re-awakening of attitudes towards nature in cities.

\section{Urban design and the expanded field of medicine+}

The built environment plays a huge part in determining population health. Urban designers can play a significant part in improving or exacerbating many health outcomes through their design decisions. The WHO (1946) defines health as "a state of complete physical, mental and social well-being"; twenty-first century urban populations are facing myriad health challenges: non-communicable diseases, climate change-induced hazards, new communicable diseases, ageing populations and socio-lifestyle risks (WHO 2020a). Health is a complex nexus of inter-related factors that impact on human and planetary health. More than half of the world is now living in urban environments, a figure set to increase by 2.5 billion by 2050 (UN Department of Economic and Social Affairs 2018). Urban environments impact, or structure, many of the key determinants of health for the majority of the global population. As such, the role of urban design as a determinant of health is increasingly recognised and the mechanisms through which it affects and impacts individual and societal wellbeing are acknowledged, particularly as contemporary health challenges require interdisciplinary solutions (Azzopardi-Muscat et al. 2020; Barton and Grant 2013; Carmichael et al. 2019). A "unified front is needed to turn the tide" against these urban lifestyle health issues (Bloom et al. 2012). In response, medicine is radically departing from its more traditional realm of doctors, nurses, hospitals and pharmaceuticals to embrace an 'expanded field' of professions, practices, approaches and policies (Geddes et al. 2011; Royal Society for Public Health 2015). This expanded field of medicine (aka medicine + or medicineplus) includes a diverse range of professionals not typically considered part of the medical world. One definition of medicine + would include an urban designer as someone: "not a specialist or practitioner in public health, but has the opportunity or ability to positively impact health and wellbeing through their... work" (Centre for Workforce Intelligence (CfWI) and Royal Society for Public Health (RSPH) 2015). One of the unintended (but arguably welcome) consequences of Covid-19 is the rethinking towards how stakeholders and actors might play their part in delivering health and medicine+. In the midst of the Covid-19 event, 'key workers' include (along with doctors, nurses, carers, etc.) a heterogenous assemblage of delivery drivers, shelf-stackers, fruit pickers, refuse collectors, public service broadcasters, teachers, border security, postal workers and telecommunications engineers (Department for Education
2020). This incongruous collection of workers illustrates how an expanded field of medicine+ might look, and urban designers should be added to that list.

\section{Healthier urban design}

The WHO has called for 'health in all policies' to ensure that health is included in every policy and decision-making process across a wide range of disciplines and industries (and has been one of the drivers behind expanding the field of medicine+). 'Health in all policies' is slowly beginning to be implemented as a 'health in all designs' strategy (sometimes referred to as 'design for health') (Rice 2019). There are clear implications for the urban design profession, with concomitant changes required to the profession's guiding values and principles with a refocus onto health. In a postCovid-19 context, if urban design is to embed health at its core, it will need to alter the DNA of its values and beliefs.

Health has been ignored in most of the 'canonical' urban design texts and theories. If we examine urban design literature for reading lists for the majority of Urban Design courses at Universities (Araabi 2016), these key books rarely, if ever, address health or wellbeing. For example, the seminal urban design texts: Image of the City (Lynch 1960), Architecture of the City (Rossi 1982), Responsive Environments (Bentley et al. 1985) and Learning from Las Vegas (Venturi et al. 1977) do not mention 'health' at all, whilst Concise Townscape (Cullen 1961), Urban Design Compendium (Davies 2000), Life Between Buildings (Gehl 1971), A New Theory of Urban Design (Alexander et al. 1987) and Collage City (Rowe and Koetter 1978) only mention 'health' a handful times at most. It is clear that the central tenets of urban design theory have not been explicitly concerned with health. Nonetheless, it could be argued that many urban design texts and guidelines do relate indirectly to health in their ambition to produce improved contexts for human habitation. However, if the urban design profession is to embed health at its core, it needs to explicitly and directly re-connect health into its founding principles. The Covid-19 event is perhaps an appropriate juncture for 'health' to be considered as a new tenet for the urban design profession?

\section{Urban design as spatial medicine+}

There are many aspects of a healthy city that lie outside the auspices of an urban designer's role-nevertheless there is still a significant range of health determinants that are controlled by the urban design profession. "Design can be defined as the human nature to shape and make our environment in ways without precedent in nature, to serve our needs and give meaning to our lives" (Heskett 2002, 
p. 7). Design spans across numerous aspects of the urban condition and it is important to understand the relationality across those scales. Urban designers play their part in the widespread practice of design in the contemporary world (most of which is designed to some extent) "from the details of daily objects to cities, landscapes, nations, cultures, bodies, genes, and ... nature itself" (Latour 2008 , p. 2). The post-Covid-19 practice of urban design may be described as a form of 'spatial medicine' (Fig. 1).

The term medicine, etymologically derived from the Latin 'medeor' meaning a 'healing art', is fitting as urban design is both an art and a science, and good urban design can contribute as a 'healing art'. As medicine moves away from prescribing pills, it transfers towards 'social prescribing' and 'nature prescribing' which direct people to undertake restorative activities or engage with the natural world in order to improve their health. Healthy urban design can become a form of 'spatial prescribing' whereby designs would actively and systematically aim to create healthier urban environments in which societies' and individuals' wellbeing can flourish. Urban designers imagineer, vision, curate and create new built environments and are involved in modifying, retrofitting and regenerating existing urban areas, as such they hold a unique position to improve health in a number of ways (Marsh et al. 2020). The expertise, competences, capacity and creativity of urban designers provide a potential roadmap for innovative, experimental and radical approaches to enabling healthier urban lifestyles.

\section{Aspects of urban design to ensure health}

There are already many guidance documents on the salient aspects of urban design to be considered. Across a range of different texts, articles and books, there is a commonly agreed set of principles, if we take those described by Carmona et al. (2010), a frequently cited source for urban designers, there are six sub-categories:

1. Morphological dimension

2. Perceptual dimension

3. Social dimension

4. Visual dimension

5. Functional dimension

6. Temporal dimension

These sub-categories comprise the wide range of issues that impact on humans, the natural world and planetary health. The terminology differs across authors but the content is broadly the same. Whilst it might be tempting to add a 'health dimension' that would perhaps not be appropriate nor optimal, health should be integrated into these six categories instead. The goal of healthy urban design should be constituted within these six dimensions. Carmona et al. (2010, p. 3) describe urban design today as "the process of making better places for people than would otherwise be produced"; this is not a particularly high benchmark and evidently not one that assures good health outcomes nor improves wellbeing. Thus, the aim of healthy urban design is not to add more categories or dimensions for urban designers to contemplate, rather the required change being the level of
Fig. 1 The nexus of urban design as spatial medicine+

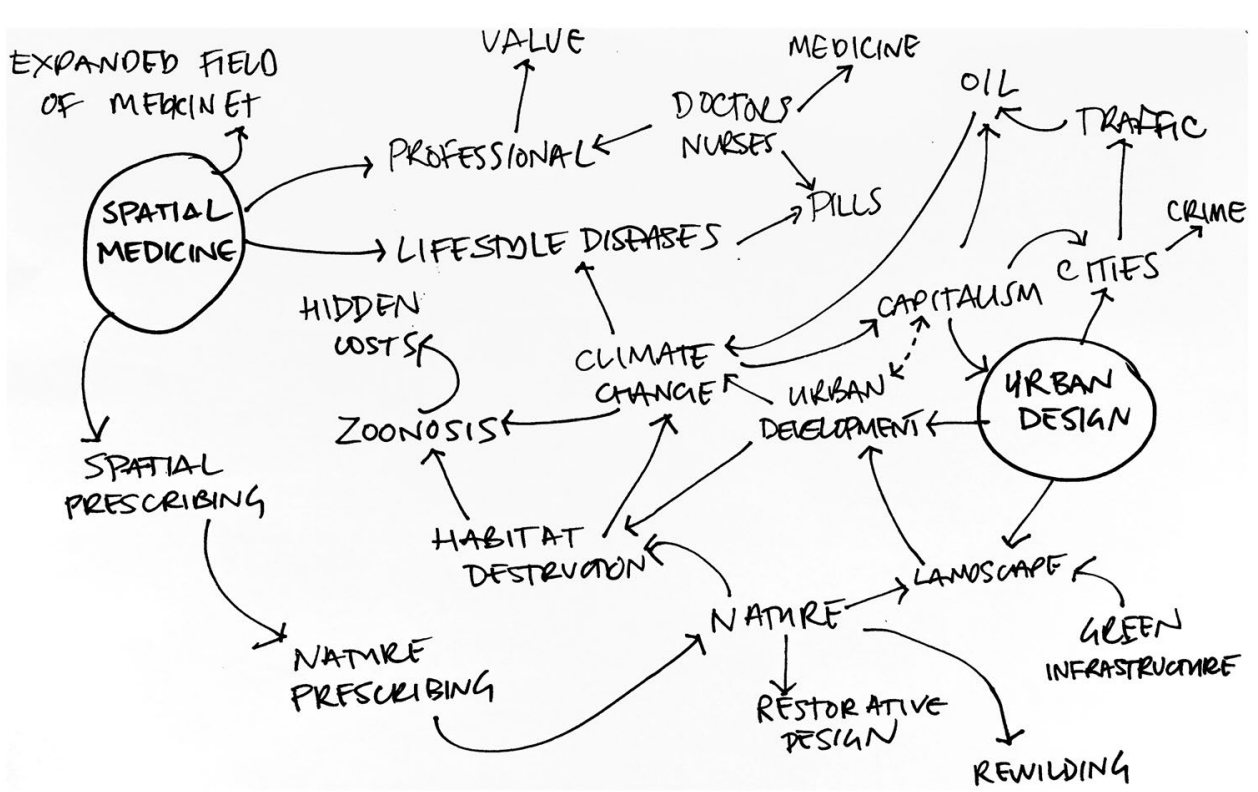


commitment and nature of ambition to achieve urban design outcomes that can improve human health.

\section{Prioritising nature}

As part of the transition towards wellbeing, one aspect of mainstream urban design urgently needs to be challengedour relationship with nature. Many of the existing key urban design texts, books, precedents and guidance documents underplay or undervalue the significance of natural world. New and existing urban contexts must respond to the biological world and rebalance the ecological system far better than previously. The call for a reconnection to nature and need to "live in harmony with nature" (Attenborough 2019) relates directly to Covid-19. The current scientific consensus is that Coronavirus originated in animals and made the leap to human species very recently (Calisher et al. 2020). Evidence suggests that Covid-19 came about as anthropogenic activities, population growth, urbanisation and the concomitant reduction in habitats for wild plants and animals have exerted too much pressure on the natural world and the rise in new communicable diseases (Daszak et al. 2000; Ahmed et al. 2019). The impacts and drivers of anthropogenic activities are manifold from climate change, plastic pollution, species extinction, industrial agriculture, overconsumption of resources as well habitat destruction (Díaz et al. 2015). Unprecedented population growth and urbanisation "lead to encroachment into natural habitats and closer encounters with wildlife and zoonoses, and... provides opportunities for zoonotic infections" (Lee et al. 2020), i.e. an increase in new diseases transmitted from animals to humans as we encroach into, disrupt and degrade the natural world (Fig. 2).

Prior to Covid-19, the rise of these new communicable diseases was deemed a "hidden 'cost' of human economic development" (Jones et al. 2008). The 'hidden costs' of mistreating nature in this way are now being revealed through the impacts of Covid-19. Not enough urban design guidance assesses the importance of the natural world sufficiently important. The Intergovernmental Platform on Biodiversity and Ecosystem Services (IPBES) main goal is "strengthening the science-policy interface for biodiversity and ecosystem services for the conservation and sustainable use of biodiversity, long-term human well-being and sustainable development" (IPBES 2020). This goal should also form the guiding principle of post-Covid-19 urban designsustainability, wellbeing and nature. There is a need for greatly expanding the presence and function of nature in urban areas by rewilding cities, bringing nature back into everyday contact with urban residents, provide urban agricultural opportunities, implementing green infrastructure and planting billions of trees. There are myriad rewards from these greener solutions, not just for the natural world, but

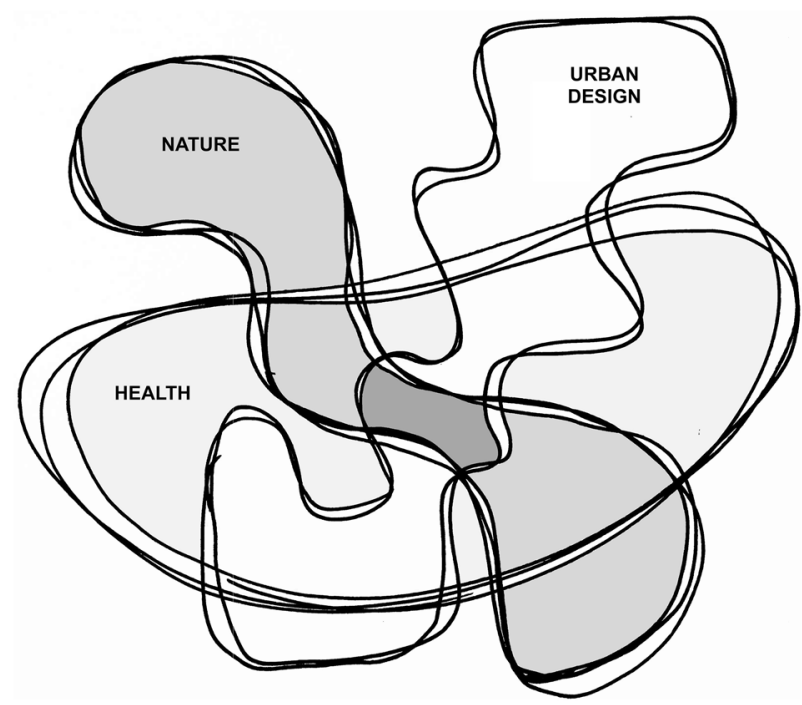

Fig. 2 Healthy urban design: the intersection of urban design, health and nature

also economic, social, climatic and health benefits (Ulrich 1984; Hartig et al. 1991; Kaplan 1993; Elmqvist et al. 2015; Kabisch et al. 2017). This greenification has the potential to transform urban realms into much more natural, wilder and restorative places.

\section{Summary}

As we move out of the Covid-19 period, a range of other related health issues may emerge. Health has previously been much lower down in priority for most decision-makers which tend to regard economic issues more highly. If we return to business-as-usual as in the pre-Covid-19 era, politicians, industry and communities must reflect on the large range of health risks that were previously deemed 'acceptable' or economically unavoidable. For example, according to the WHO (2020b) "air pollution kills an estimated seven million people worldwide every year", these deaths mostly occur in urban areas and could be largely avoidable through the implementation of healthier urban design. Air pollution is merely one risk factor responsible for mortality, there are many other pre-Covid-19 urban health issues that may return if action is not taken. Will the decision-makers of post-Covid-19 consider it acceptable to permit a return to so many millions of (largely avoidable) deaths, particularly having made such an effort to avoid deaths from a different source? If so, it questions the logic of nearly bankrupting the global economy in order to save lives from one health risk-if only to return to a situation of harming human life via other urban risks? Covid-19 has in the short term brought new focus and foregrounding of health, and when 
we transition to the post-Covid-19 era there must be more awareness and foregrounding of health and evidence-based decisions for urban design.

\section{References}

Ahmed, S., J.D. Dávila, A. Allen, M. Haklay, C. Tacoli, and E.M. Fèvre. 2019. Does urbanization make emergence of zoonosis more likely? Evidence, myths and gaps. Environment and Urbanization 31 (2): 443-460.

Alexander, C., H. Neis, A. Anninou, and I. King. 1987. A new theory of urban design. Oxford: Oxford University Press.

Araabi, H.F. 2016. A typology of urban design theories and its application to the shared body of knowledge. Urban Design International 21 (1): 11-24.

Attenborough, D. 2019. New deal for nature. Speech to World Economic Forum, Davos 2019. 22 January 2019. https://www.wwf. org.uk/updates/sir-david-attenborough-calls-new-deal-nature. Accessed 2 May 2020.

Azzopardi-Muscat, N., A. Brambilla, F. Caracci, and S. Capolongo. 2020. Synergies in Design and Health. The role of architects and urban health planners in tackling key contemporary public health challenges. Acta Biomed 91 (3): 9-20.

Barton, H., and M. Grant. 2013. Urban planning for healthy cities. Journal of Urban Health 90 (1): 129-141.

Bentley, I., A. Alcock, P. Murrain, S. McGlynn, and G. Smith. 1985. Responsive environments: A manual for designers. Oxford: Architectural Press.

Bloom, D.E., E. Cafiero, E. Jané-Llopis, S. Abrahams-Gessel, L.R. Bloom, S. Fathima, A.B. Feigl, T. Gaziano, A. Hamandi, M. Mowafi, and D. O'Farrell. 2012. The global economic burden of noncommunicable diseases. Geneva: World Economic Forum. http://www3.weforum.org/docs/WEF_Harvard_HE_GlobalEcon omicBurdenNonCommunicableDiseases_2011.pdf. Accessed 22 Sept 2019.

Calisher, C., D. Carroll, R. Colwell, R.B. Corley, P. Daszak, C. Drosten, L. Enjuanes, J. Farrar, H. Field, J. Golding, and A. Gorbalenya. 2020. Statement in support of the scientists, public health professionals, and medical professionals of China combatting COVID19. The Lancet 395 (10226): 42-43.

Carmichael, L., T.G. Townshend, T.B. Fischer, K. Lock, C. Petrokofsky, A. Sheppard, and F. Ogilvie. 2019. Urban planning as an enabler of urban health: Challenges and good practice in England following the 2012 planning and public health reforms. Land Use Policy 84: 154-162.

Carmona, M., T. Heath, S. Tiesdell, and T. Oc. 2010. Public places, urban spaces: The dimensions of urban design. London: Routledge.

Centre for Workforce Intelligence (CfWI) and the Royal Society for Public Health (RSPH). 2015. Understanding the wider public health workforce. London: CfWI.

Daszak, P., A.A. Cunningham, and A.D. Hyatt. 2000. Emerging infectious diseases of wildlife-threats to biodiversity and human health. Science 287 (5452): 443-449. https://doi.org/10.1126/ science.287.5452.443.

Department for Education. 2020. Critical workers who can access schools or educational settings. https://www.gov.uk/government /publications/coronavirus-covid-19-maintaining-educationa 1-provision/guidance-for-schools-colleges-and-local-authoritie s-on-maintaining-educational-provision. Accessed 2 May 2020.

DeSantis, R. 2020. Half of earth's population is now on coronavirus lockdown as cases exceed 1 million. The people, 3 April. https ://people.com/human-interest/half-world-coronavirus-lockdowncases-exceed-1-million/. Accessed 1 May 2020.

Díaz, S., S. Demissew, J. Carabias, C. Joly, M. Lonsdale, N. Ash, A. Larigauderie, J.R. Adhikari, S. Arico, A. Báldi, and A. Bartuska. 2015. The IPBES conceptual framework-Connecting nature and people. Current Opinion in Environmental Sustainability 14: $1-16$.

Dore, B. 2020. Covid-19: Collateral damage of lockdown in India. $B M J$. https://doi.org/10.1136/bmj.m1711.

Douglas, M., S.V. Katikireddi, M. Taulbut, M. McKee, and G. McCartney. 2020. Mitigating the wider health effects of covid-19 pandemic response. BMJ. https://doi.org/10.1136/bmj.m1557.

Elmqvist, T., H. Setälä, S.N. Handel, S. Van Der Ploeg, J. Aronson, J.N. Blignaut, E. Gómez-Baggethun, D.J. Nowak, J. Kronenberg, and R. De Groot. 2015. Benefits of restoring ecosystem services in urban areas. Current Opinion in Environmental Sustainability 14: $101-108$.

Geddes, I., J. Allen, M. Allen, and L. Morrisey. 2011. The Marmot Review: Implications for spatial planning. London: The Marmot Review Team, NICE.

Gehl, J. 1971. Life between buildings: Using public space. London: Island Press.

Cullen, Gordon. 1961. The concise townscape. Oxford: Architectural Press.

Hartig, T., M. Mang, and G.W. Evans. 1991. Restorative effects of natural environment experiences. Environment and Behavior 23: 3-36.

Heskett, J. 2002. Toothpicks and logos: Design in everyday life, vol. 1. Oxford: Oxford University Press.

IPBES. 2020. What is IPBES? Establishment of IPBES. https://ipbes .net/about. Accessed 29 Apr 2020.

Jones, K.E., N.G. Patel, M.A. Levy, A. Storeygard, D. Balk, J.L. Gittleman, and P. Daszak. 2008. Global trends in emerging infectious diseases. Nature 451 (7181): 990-993.

Kabisch, N., M. van den Bosch, and R. Lafortezza. 2017. The health benefits of nature-based solutions to urbanization challenges for children and the elderly-A systematic review. Environmental Research 159: 362-373.

Kaplan, R. 1993. The role of nature in the context of the workplace. Landscape \& Urban Planning 26 (1-4): 193-201.

Latour, B. 2008. A cautious Prometheus? A few steps toward a philosophy of design (with special attention to Peter Sloterdijk). Proceedings of the 2008 annual international conference of the design history society; 3-6 September 2008, Florida: Universal Publishers, pp. 2-10.

Lee, V.J., M. Ho, C.W. Kai, X. Aguilera, D. Heymann, and A. WilderSmith. 2020. Epidemic preparedness in urban settings: New challenges and opportunities. The Lancet Infectious Diseases 20 (5): 527-529. https://doi.org/10.1016/S1473-3099(20)30249-8.

Llewelyn, Davies. 2000. Urban design compendium. London: English Partnerships/Housing Corporation.

Lynch, K. 1960. The image of the city. Cambridge, MA: MIT Press.

Marsh, R., P. Pilkington, and L. Rice. 2020. A guide to architecture for the public health workforce. Public Health 178: 120-123.

Rice, L. 2019. A health map for architecture: The determinants of health and wellbeing in buildings. In Designing for health \& wellbeing: Home, city, society, ed. M. Jones, L. Rice, and F. Meraz, 155-184. Delaware: Vernon Books.

Rossi, A. 1982. The architecture of the city. Cambridge, MA: MIT Press.

Rowe, C., and F. Koetter. 1978. Collage city. Cambridge, MA: MIT press.

Royal Society for Public Health. 2015. Rethinking the public health workforce. London: Royal Society for Public Health.

Ulrich, R.S. 1984. View through a window may influence recovery from surgery. Science 224 (4647): 420-421. 
UN Department of Economic and Social Affairs. 2018. World urbanization prospects: The 2018 Revision of World Urbanization Prospects. UN Report. https://www.un.org/development/desa/publi cations/2018-revision-of-world-urbanization-prospects.html. Accessed 2 May 2020.

Venturi, R., D.S. Brown, and S. Izenour. 1977. Learning from Las Vegas: The forgotten symbolism of architectural form. Cambridge, MA: MIT Press.

WHO. 1946. Charter of the World Health Organization. Geneva: WHO.

WHO. 2020a. Health risks in cities. Geneva: WHO. https://www.who. int/sustainable-development/cities/health-risks/en/. Accessed 9 May 2020.
World Health Organization. 2020b. Air pollution. WHO report data. https://www.who.int/health-topics/air-pollution\#tab=tab_1. Accessed 18 Apr 2020.

Publisher's Note Springer Nature remains neutral with regard to jurisdictional claims in published maps and institutional affiliations. 